\title{
Hvorfor har lungemedisinsk avdeling behov for mottaksleger?
}

KOMMENTAR

\section{KRISTIN KORNELIA UTNE}

E-post: kristin.kornelia.utne@legeforeningen.no Kristin Kornelia Utne er leder for Yngre legers forening. Forfatteren har ikke oppgitt noen interessekonflikter.

Dr. May Britt Lund problematiserer Yngre leger forening (Ylfs) kamp mot stillinger som «mottakslege». Hun løfter videre manglede antall LIS1-stillinger (1).

Vi i Ylf er helt enige i at mangelen på LIS1-stillinger er et stort problem. Det er ikke samsvar mellom antall medisinstudenter, utdanningsstillinger og behov for legespesialister. Norge har god tilgang på leger, men mangler legespesialister i både allmenn- og sykehusmedisin. Det er altså ikke antallet medisinstudenter som er problemet, men at antallet utdanningsstillinger ikke dimensjoneres ut i fra spesialistbehov.

Dette er grunnen til at Ylf, Norsk medisinstudentforening ( $\mathrm{Nmf}$ ) og Legeforeningen har jobbet intenst opp mot myndighetene sikre 200 flere LIS1-stillinger i året. På lengre sikt $\emptyset n s k e r$ vi en fortløpende evaluering av spesialistbehovet, med tilsvarende regulering i utdanningsstillinger (LIS1-2-3). Dette har vi kommunisert i møte med politikere, demonstrert for foran Stortinget, og ikke minst løftet i utallige saker i media. Helsedirektoratet er enige i at 200 nye LIS1-stillinger er nødvendig for å dekke fremtidens spesialistbehov.

Men vi er ikke i mål. Selv om vi har fått noen ekstra stillinger de siste årene, øker ikke myndighetene antallet LIS1-stillinger i takt med behovet for spesialister.

Helse- og omsorgsdepartementet fastsetter antallet LIS1-stillinger, og har dialog med helseforetakene om hvor mange LIS1-leger de kan ta imot. Til tross for at mange sykehus melder om behov for flere LIS1, angir de regionale helseforetakene at de ikke trenger eller har kapasitet til flere LIS1. Foretakene er svært presset på økonomi og selvfølgelig ønsker at nye LIS1-stillinger skal finansieres med friske midler fra staten. Samtidig har finansdepartementet mange andre poster å bevilge midler til.

Det er altså «manglende kapasitet» til å ansette flere LIS1, men behovet for arbeidskraft er stort og avdelingene ansetter derfor «mottaksleger». At disse stillingene skal være faste er ikke et krav fra Ylf, men følger av loven. OUS ble i $2019 \mathrm{~d} ø \mathrm{mt}$ i retten for ulovlig midlertidige ansettelse av en mottakslege, da vedkommende ikke fylte en annens fravær.

Ylf er ikke imot at medisinstudenter eller nyutdannede leger tilegner seg erfaring gjennom reelle vikariater i tjenesten. Men vi er svært urolige for en utvikling der det opprettes en 
rekke stillinger utenom utdanningssystemet som skjuler en overbelastet og underbemannet helsetjeneste. I Danmark arbeider 4500 «reserveleger» på sykehus, en stilling som ikke gir tellende tjeneste i spesialistutdanningen. Jo flere de blir, jo lengre må legene jobbe for å kvalifisere seg til videre spesialistutdanning. Foretakene presser ikke på for flere utdanningsstillinger, de kan drifte sykehusene ved at nyutdannede kolleger gjør forefallende legearbeid.

Hvorfor trenger lungemedisinsk avdeling på Rikshospitalet mottaksleger? OUS, landets absolutt største helseforetak, ansetter 15 LIS1 per halvår, langt færre enn Møre- og Romsdal. Dersom avdelingen faktisk har mange oppgaver som skal og bør løses av nyutdannede leger, hvorfor har de ikke LIS1-stillinger?

Det er dette vi sammen må løfte for å sikre våre kolleger.

\section{LITTERATUR:}

1. Lund MB. Forbud mot mottaksleger: kun en symbolseier? Tidsskr Nor Legeforen 2020; 140. doi: 10.4045/tidsskr.20.0633. [PubMed][CrossRef]

Publisert: 26. oktober 2020. Tidsskr Nor Legeforen. DOI: 10.4045/tidsskr.20.0788

(C) Tidsskrift for Den norske legeforening 2020. Lastet ned fra tidsskriftet.no 